\title{
Impact of Technical and Vocational Education on Manpower Development in South-West Nigeria
}

\author{
Obadara, Olabanji E. (Ph.D.) \\ Department of Educational Management, \\ Tai Solarin University of Education, Ogun State, Nigeria. \\ doctorobadara@yahoo.co.uk \\ S.O. Oyebolu \\ Department of Vocational \& Technical Education, \\ Tai Solarin College of Education, Omu-ljebu, Ogun State.
}

\section{Doi:10.5901/mjss.2013.v4n3p409}

\begin{abstract}
The study examined the contribution of technical and vocational education to manpower development in south-west Nigeria. Descriptive survey research design was used for the study. The sample of 20 industries was drawn, which were typically manufacturing industries in the south-west Nigeria using purposive sampling technique. While a total number of 78, 337 workers were sampled in all the 20 industries for the study. A self-developed checklist titled "Technical and Vocational Education Manpower Development Checklist (TVEMDC)" with a cronbach-alpha reliability coefficient ( $\alpha=0.78)$ was used for data gathering. Descriptive statistic of percentages as well as inferential statistic of Pearson product moment correlation was used for the data analysis. The findings revealed a very low percentage of technical and vocational education graduates employed by the industries in south-west Nigeria, and significant contribution of technical and vocational education to manpower development in south west Nigeria. It is therefore concluded among others that the nation' universities, polytechnics, and colleges should be up and doing in exposing the technical and vocational trainees to new ideas and technologies so as to be relevant in the world of work and integrate more quickly into the global economy, as businesses restructure their supply chain and operations to gain from regional comparative advantages.
\end{abstract}

Keywords: Human resource, Technical and vocational training, World of work, Self-reliance, Efficiency.

\section{Introduction}

In recent times, the development of human capital has been the focus of concern towards the development of a nation. This is a fact that the growth of tangible capital stock of a nation depends to a considerable degree on human capital development. Without adequate investment in developing the human capital which is the process of increasing knowledge, skills and the capacities of people in the country, the possibility of the growth of that nation might be minimal. It is apparent that employment and occupational skills can be provided by technical and vocational education. Technical education is that aspect of education that involves the acquisition of techniques and application of the knowledge of the science for the improvement of man's surrounding. Technical and vocational education prepares one for the world of work with which the individual becomes self-reliant and can make contributions to the development of the society. As employers look for new talents every year from new graduates, it is important to look for not only those who have solid education, but graduates that have features that stand out from the rest of the graduating students.

Manpower development has to do with organized learning activities arranged in a well organised setting for the purpose of improving performance and/or personal growth so as to improve the job, the individual, and/or the organization. This includes the broader range of activities to develop personnel inside of the organizations including for example, areas of training and development, career development, and organization development. Human resource development (HRD) in totality is a dynamic, ongoing, continuing, empowering process. The individual human being's growth is multidimensional, influencing the cognitive, affective, physical and spiritual facets of the human person. These definitions recognize the strengths and limitations of people as well as their potentials. The goal of HRD is to improve the performance of the organizations by maximizing the efficiency and performance of the people. It develops employees' knowledge and skills, actions and standards, motivation, incentives, attitudes and work environment. 
Technical and vocational education is essential education, which is intended to provide the skills and the manpower for industry and other engineering services required by society. Therefore, vocational education programme is designed to prepare skilled workers for industry, agriculture, commerce, etc from the post secondary level. That is why the programme includes general studies, practical training for the development of skills required by the chosen occupation and related theory (Olaitan, 1996). There is no doubt that technical and vocational education (TVE) plays a significant role in the socio-economic growth and development of a country. Technical and vocational education is a type of education that prepares manpower for sustainable national development. It provides employable skills to reduce poverty, helped to apply acquired knowledge and skills for scientific and technological development and advancement of the nation.

According to Smith (1991), vocational education in its broad sense refers to the training that enables one to carry on successfully a socially useful occupation. This definition refers to vocational education as training for useful employment in trade and industrial, agricultural, business and home making among others. Manpower on the hand according to Okorie (2000) could be seen as the total supply of person available and fitted for service. Thus vocational education prepares manpower since according to Olaitan (1992), vocational education is a process of getting people ready and keeping them ready for the types of service we need. Vocational education is thus a sine-qua-non for manpower development.

Enebe (2000) highlights the significant roles which TVE can play in curbing unemployment and in providing the needed skilled labour for industrialization. According to Enebe (2000), "technical education stresses the engineering aspect of vocational education such as electronics, electrical, mechanical and automobile works". Thus, both vocational education and technical education aim at developing, among others, useful skills for productive purposes. The world has become aware in recent times of the magnitude of the changes resulting from advances in and the intensive application of technology. Science and technological knowledge have become so important that today; they have replaced capital as society's most important resources. The efficiency of the system of TVE of a nation is a major factor that determines its economic well-being, its standard of living, its potential growth and security.

\section{Purpose of the Study}

The purpose of this paper is to empirically establish the contribution of technical and vocational education to manpower development in south-west Nigeria with the aim of using its findings to make useful recommendations on how to strengthen quality of technical and vocational education programmes for the development of manpower in Nigeria.

\section{Research Questions}

1. What is the numerical strength of the technical and vocational education graduates employed by the industries in south-west Nigeria?

2. What is the percentage of the technical and vocational education graduates employed by the industries in south-west Nigeria?

3. Is there any significant contribution of technical and vocational education to manpower development in southwest Nigeria?

\section{Research Procedure}

Descriptive survey research design was used for the study. The sample of 20 industries was drawn, which were typically manufacturing industries in the south-west Nigeria using purposive sampling technique. While a total number of 78,337 workers were sampled in all the 20 industries used for the study. It should be noted that all the industries used for the study have branches across south west Nigeria. A self-developed checklist titled "Technical and Vocational Education Manpower Development Checklist (TVEMDC)" with a cronbach-alpha reliability coefficient $(\alpha=0.78)$ was used for data gathering. Descriptive statistic of percentages as well as inferential statistic of Pearson product moment correlation was used for the data analysis.

\section{Results and Discussion}

The data collected were analysed and the results of the study are presented according to the generated research 
questions.

Q 1: What is the numerical strength of the technical and vocational education graduates employed by the industries in south-west Nigeria?

Q 2: What is the percentage of the technical and vocational education graduates employed by the industries in south-west Nigeria?

Table 1: Total Number of Technical and Vocational Education Graduates Employed in Various Establishment in SouthWest Nigeria

\begin{tabular}{|c|c|c|c|c|}
\hline $\mathrm{S} / \mathrm{N}$ & Organization / Establishment & $\begin{array}{l}\text { Total No. } \\
\text { of Staff }\end{array}$ & \begin{tabular}{|c|} 
Total No. of TVE \\
Graduates Among Staff
\end{tabular} & $\begin{array}{l}\% \text { Of TVE Graduates } \\
\text { Among Staff }\end{array}$ \\
\hline 1 & Cadbury Nigeria Lateef Jakande Road, Ikeja,Lagos. & 2,000 & 120 & 6 \\
\hline 2 & $\begin{array}{l}\text { Coca-Cola Nigeria Plc, Pemberton Place,16, Gerrard Rd, } \\
\text { lkoyi,Lagos. }\end{array}$ & 6,000 & 320 & 5.3 \\
\hline 3 & Dangote Group & 12,000 & 400 & 3.3 \\
\hline 4 & Friesland Foods, Wamco Nigeria Plc. Ikeja Lagos. & 14,582 & 576 & 4 \\
\hline 5 & Guinness (Nigeria) Plc, 24 Oba Akran Avenue, Ikeja, Lagos. & 1,450 & 109 & 7.5 \\
\hline 6 & $\begin{array}{l}\text { May and Baker Nigeria Plc. No 3/5 Sapara Street Industrial } \\
\text { Estate,Ikeja Lagos. }\end{array}$ & 1,520 & 20 & 1.3 \\
\hline 7 & $\begin{array}{l}\text { Neimeth International Pharmaceuticals Plc, 1, Henry Carr } \\
\text { Street, Ikeja Industrial Estate, Lagos. }\end{array}$ & 1,750 & 42 & 2.4 \\
\hline 8 & $\begin{array}{l}\text { Nigerian Breweries Plc, Iganmu House, } 1 \text { Abebe, Village } \\
\text { Road, Lagos. }\end{array}$ & 1,332 & 390 & 29.3 \\
\hline 9 & $\begin{array}{l}\text { Nigerian German Chemicals Plot } 144 \text { Oba Akran Avenue } \\
\text { Ikeja, Lagos. }\end{array}$ & 1,989 & 35 & 1.8 \\
\hline 10 & Nigerite Limited, Oba Akran Avenue,Ikeja, Lagos. & 4,850 & 67 & 1.4 \\
\hline 11 & $\begin{array}{l}\text { Pharma Deko Plc, Plot C15/3 Agbara Industrial Estate, } \\
\text { Agbara, Ogun State. }\end{array}$ & 102 & 12 & 11.8 \\
\hline 12 & Promasidor Plc, 23 Wharf Road, Apapa, Lagos. & 5,000 & 44 & 0.9 \\
\hline 13 & $\begin{array}{l}\text { PZ Industries/Unilever Plc, 45/47 Town Planning Way Illupeju } \\
\text { Industrial Estate Ikeja, Lagos. }\end{array}$ & 5,249 & 340 & 6.5 \\
\hline 14 & $\begin{array}{l}\text { Nestlé Nigeria Plc, 22/24 Industrial Avenue, Ilupeju, Ikeja, } \\
\text { Lagos. }\end{array}$ & 10,000 & 1690 & 16.9 \\
\hline 15 & $\begin{array}{l}\text { Seven Up Bottling Company } 247 \text { Moshood Abiola Way, ljora } \\
\text { Lagos. }\end{array}$ & 3,500 & 65 & 1.9 \\
\hline 16 & $\begin{array}{l}\text { Tura International Limited 21B Akin Adesola Street, Victoria } \\
\text { Island, Lagos. }\end{array}$ & 233 & 14 & 6 \\
\hline 17 & Dunlop Nigeria Plc, Plot 23, Oba Akran Avenue, Ikeja, Lagos. & 3,775 & 43 & 1.1 \\
\hline 18 & $\begin{array}{l}\text { British American Tobacco (Nigeria) Limited PC } 35 \text { Idowu, } \\
\text { Taylor Street, VI Lagos. }\end{array}$ & 10,000 & 149 & 1.5 \\
\hline 19 & $\begin{array}{l}\text { IdeaGates Concept Nig. Ltd. } 12 \text { Rehoboth Plaza Jericho, } \\
\text { Ibadan Oyo State }\end{array}$ & 105 & 10 & 9.5 \\
\hline \multirow[t]{2}{*}{20} & $\begin{array}{l}\text { Tosh Commodities (Nig) Ltd. Km } 2 \text { New Ife Road Ibadan Oyo } \\
\text { State }\end{array}$ & 100 & 05 & 5 \\
\hline & TOTAL & 78,337 & 4,451 & 5.7 \\
\hline
\end{tabular}

The table 1 above shows total number of workers, the total number of technical and vocational education graduates among workers and their percentages in each of the 20 industries used for the study. The analysis shows that the highest number of the technical and vocational education graduates among the employed workers is 1690 recorded by Nestle Nigeria Plc. representing 16.9 of its total work force. While the Nigerian Breweries had the highest percentage of technical and vocational education graduates among its staff, which is $29.3 \%$. Promasidor Plc. has the least percentage of $0.9 \%$ of technical and vocational education graduates among its total number of 5000 workers. This might not be unconnected with the fact that it is a pharmaceutical industry, which may not necessarily need much of these graduates by the nature of its products. This is because all the pharmaceutical industries sampled have very low percentages of technical and vocational education graduates among their workers. In summary, this result indicates a very low 
percentage of technical and vocational education graduates employed by the industries in south-west Nigeria, which is $5.7 \%$.

Q 3: Is there any significant contribution of technical and vocational education to manpower development in southwest Nigeria?

Table 2: Contribution of Technical and Vocational Education to Manpower Development in South-West Nigeria

\begin{tabular}{|l|c|c|c|c|c|c|c|}
\hline \multicolumn{1}{|c|}{ Variable } & $\mathrm{N}$ & Mean & SD & df & Calculated(r) & Tabulated(r) & Rmks \\
\cline { 1 - 7 } Manpower Development & 78,337 & 4276.85 & 4271.524 & \multirow{2}{*}{18} & 0.588 & 0.468 & \multirow{2}{*}{ Sig. } \\
\hline Technical and Vocational Education & 4451 & 222.55 & 383.354 & & & \\
\hline
\end{tabular}

$\mathrm{P}<0.05$

The result in table 2 above reveals the contribution of technical and vocational education to manpower development in south-west Nigeria. The table shows that the r-cal $=0.588>$ greater than the $r$-tab 0.468 at 18 degree of freedom at the 0.05 level. The result indicates that technical and vocational education has significantly contributed to manpower development in south west Nigeria.

The results of this present study buttresses Enebe (2000), who asserted that this nation is in dire need of a good core of intermediate-level manpower in various industries to carry out their programmes. Craftsmen and technicians are the live wire of virtually all industrial activities. Without them, the machinery of industries will grind to a halt. Many industries are now being established in this country by both the private and public sectors of the economy and each of these industries depends mainly on the availability of craftsmen and technicians.

Technical and vocational education (TVE) remains the popular means by which trained manpower is produced for economic and industrial growth of both developed and developing countries in the world. No wonder the Federal Republic of Nigeria, specifically stated in its National Policy on Education (2004) that, "Technical and Vocational Education is used as comprehensive term referring to those aspect of the educational process involving, in addition to general education, the study of technologies and related sciences and the acquisition of practical skills, attitudes, understanding and knowledge relating to occupations in the sectors of economic and social life".

\section{Conclusion}

The aim of establishing technical and vocational education through Act No. 9 of 11th January, 1977 is to promote the production of skilled/semi-skilled technical and professional manpower, to revitalise and sustain the national economy, reduce unemployment and poverty. This system of education has been an integral part of national development strategies in many societies because of its impact on productivity and economic development.

There is no doubt the level of manpower production by technical and vocational education compared with the needs of the society for technical development has never been encouraging in Nigeria. Recently, the minister of education, Professor Ruqayyatu Rufai identified poor public perception of technical and vocational education, as part of the constraints hindering Nigerians from fully embracing the concept. According to her, the Nigerian government recognises the crucial role TVE plays in poverty eradication, job creation, sustainable development and actualisation of the transformation agenda of the present administration, hence government's efforts at widening access to Technical and Vocational Education and Training through the establishment of Vocational Enterprise Institutes (VEIs\}, and Innovation Enterprise Institutions, (IEIs). It should be noted that that Technical and Vocational Education's development is more than share establishments of institutes or institution. It needs to be supported with adequate funding and proper utilization of the fund to purchase world standard equipment and capable manpower.

\section{Recommendations}

Based on the above findings, it is therefore recommended that the low human resource development in the country needs to be tackled through a coherent and comprehensive strategy that takes full account of the policy linkages and the country's implementation capacity.

In an attempt to boost workforce skills through technical and vocational training, the interaction among educational attainment, workforce skills, population health and labour market laws and regulations must be taken into consideration.

The nation's universities, polytechnics, and colleges should be up and doing in exposing the technical and vocational trainees to new ideas and technologies so as to be relevant in the world of work and integrate more quickly 
into the global economy, as businesses restructure their supply chain and operations to gain from regional comparative advantages.

Teachers of technical and vocational education must be well grounded and possess the relevant skills that need to be imparted into those they teach.

Lastly, it is imperative to increase the number of Nigerian universities that will be running technical and vocational education as a course up to Ph.D. level so as to encourage candidates to choose the course. This is because very few universities in Nigeria have it as a course either at undergraduate or postgraduate level.

\section{References}

Enebe P. A. (2000). 'Vocational and technical education teachers in Nigeria: Issues and their

implications for vocational and technical education' In Akinmade, C.T.O., Oyetunde, T.O. and Akpa, G.O. (Eds.). Vocational and technical education teachers in Nigeria. pp. 34-44.

Federal Republic of Nigeria (2004). National policy on education. Lagos: NERDC Press.

Okorie, J. U. (2000). Developing Nigeria's work force. Calabar: Page Environs Publishers.

Olaitan, S. O. (1992). Vocational and technical education in Nigeria: Issues and analysis. Onitsha: Noble Graphic Press.

Olaitan, S. O. (1996). Mechanism for improving manpower vocational technical education and manpower development. UNN: AVA Publishers.

Smith, S. J. (1991). Vocational Education and the World of Work. Boston: Allen and Bacon Inc. 
